\title{
Actor Analysis in Case Studies for (regional) Sustainable Development
}

\author{
Simon Burandt, Fabienne Gralla, Beatrice John
}

Envigogika 10 (1) - Reviewed papers/ Recenzované články

Published/ Publikováno 19. 2. 2015

DOI: $\underline{10.14712 / 18023061.433}$

\begin{abstract}
:
Specific local situations or phenomena pose specific challenges for regional (sustainable) development. These challenges require mostly local or regional solution paths for existing social-environmental systems that have to be investigated. Here, the balance between studying and developing solution options can have a high impact on decision making and community choices.

Processes of regional (sustainable) development are controlled by social players and these are the ones who finally decide and interact. These processes can be investigated with practical relevance in order to contribute (information) to sustainable solutions, to show examples of how to steer regional development processes, how to solve existing conflicts and to deliver information for strategic development.

In this article, the actor analysis method is introduced and different options for implementation in practice are provided using a case study conducted in the Ore Mountains as illustration. The actor analysis steps described here can be read as a guideline for implementing an analysis, but the examples given are also intended to show the potential and different options whose social interaction factors could be the focus of investigation and how ideas or solutions of practical relevance can be generated.
\end{abstract}

\section{Key words:}

regional development; actor analysis; stakeholder analysis

\section{Abstrakt:}

$\checkmark$ záležitostech (udržitelného) rozvoje je třeba věnovat zvláštní pozornost situaci a jevům na místní úrovni. Řešení problémů, jež zde vznikají v sociálně-environmentálních systémech, je tak třeba hledat a zkoumat $v$ místních souvislostech. A pokud jsou právě na této úrovni snahy o studium a hledání řešení problémů v rovnováze, může to mít významný dopad na rozhodovací procesy a jejich výsledek pro místní komunity.

Do procesů regionálního (udržitelného) rozvoje vstupují sociální aktéři, a jsou to oni, kdo mezi sebou interagují a nakonec též rozhodují. Procesy vzájemné interakce mohou být zkoumány z praktického hlediska, takže výsledek potom přispívá $k$ udržitelným řešením, a 
vede např́iklad k pochopení toho, jak by měly být řizeny rozvojové procesy, jak nakládat s existujícími konflikty, nebo jak sdílet informace nezbytné pro tvorbu strategií.

$\checkmark$ tomto článku je představena metoda analýzy aktérů, a na př́padové studii $z$ oblasti Krušných hor jsou pro ilustraci ukázány možnosti, jak ji využít $v$ praxi. Kroky této metody, popsané $v$ textu, mohou sloužit jako vodítko pro její uplatnění v praxi, ale uvedené př́ipady též uvádějí spektrum možných sociálních interakcí, jimiž se lze zabývat, a představují způsoby, jimiž lze generovat nápady nebo praktická řešení.

\section{Klíčová slova:}

Regionální rozvoj; analýza aktérů; analýza sociálních hráčů 


\section{Introduction}

In this anthropocene era (Crutzen, 2006), human activities are placing pressure on the limits of Earth's system, pushing "planetary boundaries" (Rockström et al., 2009). Sustainability problems such as climate change, biodiversity loss, resource depletion, and land use change, among others, have complex cause-effect relationships extending across time and spatial scales.

Although sustainability problems have a global dimension, the regional level presents important access points into the close interactions within human-ecological systems, while specific local situations or phenomena pose specific challenges for regional (sustainable) development. These challenges require mostly local or regional solution paths for existing social-environmental systems that should be investigated (Clark 2001). Here the balance between studying and developing solution options, i.e. via transdisciplinary processes, can have a large impact on decision making and community choices (Graymore et al., 2008).

Case study research is an appropriate design that allows insights into contextualized sustainability problems ${ }^{1}$ and produces a case specific system target, and transitional knowledge (cf. Yin, 2014). On a specific case level, analysis can take on a higher resolution and it becomes visible that e.g. processes of regional development, decision-making, or (sustainability) transitions are controlled, obstructed, or facilitated by social actors and their differing interests (cf. Ackermann et al., 2003, Frischknecht and Schmidt, 2002). Therefore, case studies cannot take place without identifying relevant actors and their specific characteristics. Within these designs actor analysis may function as participatory element that allows the engagement of local stakeholders and produces these kinds of knowledge types in a viable format for empowerment.

On the one hand, placing a focus on social players adds to the transparency of responsibilities, power relations, and connections, but trade-offs of possible measurements of practical relevance can also be identified. On the other hand, providing stakeholder approaches in viable formats, such as easy to use manuals, improves an application initiated by practitioners. Despite its broad application, actor analysis has been a tool used mostly at the disciplinary level. There is a growing experience regarding the application of this method in the multi-dimensional area of sustainability problems in order to understand the potential of its results for solution development and transitional knowledge.

This article aims to illustrate the potential and feasible ways of implementing actor analysis in case studies with regional sustainability development topics. This is exemplified by the case of the Ore Mountains (see Box 1), a study on regional sustainable development. In order to do so, the background to the method is introduced in brief and a short case description is provided. Second, the method steps for (i) key stakeholder identification and (ii) stakeholder characterization are illustrated with several methodical options. They can be read as a guideline or framework for conducting an analysis in case study research.

\footnotetext{
${ }^{1}$ Mader (2009), for example, describes regional development processes from a stakeholder perspective and gives examples on: What is the vision the actors follow? Who are the stakeholders to be involved and how do they need to be involved? What information needs to be exchanged and reflected upon? How is new knowledge being generated?
} 


\section{Rationale of Stakeholder and Actor Analysis}

Actors can be individuals or collectives that act (socially) and have an interest in a specific situation or topic. They can act in the system, influence processes, and own power, legitimacy or important resources (Schimank, 2007). Often the term "stakeholder" is used. "A stakeholder can be any relevant person, group or organization with an interest in the issue, either because he is going to be affected by the subject (victim, gainer) or because he has influence, knowledge or experience with the subject" (EC 2003, Annex I). Stakeholders include all individuals, groups or organizations that are directly concerned with actions that others take to solve the problem or deal with the issue (Gray, 1989). The terms "actor" and "stakeholders" are used synonymously here.

Actor and stakeholder analysis originate in management theory ${ }^{2}$ and political science $^{3}$. In business management the aim is primarily to identify relevant stakeholders regarding the plans and projects of a company (Reed et al. 2009). Actor analysis helps to identify groups and individuals outside of a firm in order to investigate the mechanism of cooperation, or threats and opportunities. Whereas political scientists and natural resource managers use stakeholder analysis to avoid a marginalization of relevant actors in decision-making processes (Reed et al. 2009), for example, analysing intergovernmental decision making processes, or actors which affect or are affected by particular policies (Hermans 2005; Wever, et al. 2015). Actor analysis connects management approaches with social sciences and combines applicability in practice with sound scientific analyses. The analysis takes place in a formalized process. Stakeholder analysis is often less formalized then actor analysis, but there is no clear division between the two terms.

Nowadays, the method is chosen when individual and collective actors and their relationships, interactions and social actions are the focus of investigation. In practice, actor analysis serves as local tool to empower citizens, such as for work in developing countries undertaken by the German Federal Enterprise for International Cooperation (GIZ). Within the sustainability context, actor analysis finds application mostly in studies of environmental issues, such as climate change communication (e.g. Radost; cf. The BACC Author Team, 2008), and water management and practices (Wever et al., 2015).

\section{Steps in Actor Analysis}

As described in the introduction, different actors' interests, attitudes, power etc. play an important role on the regional scale in the context of sustainable development, and therefore case studies in this field should investigate the "actor-landscape" somehow.

In case study practice, actor analysis is implemented differently and the degree of formalization varies. In the following, three working steps in actor analysis are described. Each step will be explained with a purpose and design, and illustrated with an example of a case study which was conducted in the Ore Mountains in 2011 (see Box 1, 2). The main focus of the description is the application of actor analysis in a real world case study with a focus on existing conflicts, interactions and cooperation from the point of view of involved actors in the context of sustainable regional development.

\footnotetext{
${ }^{2}$ For example: the analyses of organizational networks and alliances, or groups and individuals outside of a firm, in order to investigate the mechanism of cooperation, or threats and opportunities.

${ }^{3}$ For example: analyzing intergovernmental decision making processes, or actors which affect or are affected by policies.
} 
The three working steps can be classified as

- Identifying actors;

- Selection of key actors and categorizing actors; and

- Analyzing and describing relationships between actors (adopted from Reed et al., 2009).

It is obvious that the focus of a case study with corresponding research questions has a great influence on which actors are relevant and should be considered within the case study. Furthermore, the geographical and time scales of the case study may be relevant. The ways in which to develop a good research question for a complete case study shall not be discussed in this article; ${ }^{4}$ however, the guiding question for the corresponding actor analysis can be derived from it. The example guiding question in the Ore-Mountains case study is presented in Box 1.

\section{Box1: Case Study "(Lignite) Mining in the Ore Mountains":}

On the Czech side of the Czech - German border region, the huge impacts of supraregional industries are visible. The region suffers from an (unregulated) mining industry, air pollution from lignite power plants, chemical factories, unemployment and, above all, bears the history of the Sudetenland with all of the attached stigmas relating to the forced migration of its inhabitants. Also the question if existing mining limits shall be extended is being discussed. The region is now is confronted with different developmental scenarios. Many conflicts of interest and powers clash together.

\section{Case Study Research Question:}

Which options and levers for action shall be taken for sustainable regional development?

\section{Guiding Questions for Actor Analysis within the case study:}

Which actors are relevant in this context? Which interactions take place? Who is affected or has an interest? What is the relevance of each player for the process of change? Which barriers, conflicts, opportunities for communication exist?

\section{Background of the Case Study:}

The case study was conducted in an international study program in 2011 with Czech and German students funded by MOSUR $^{5}$ and DBU $^{6}$ (Dlouhá \& Burandt, 2015) The students worked in four course modules on questions of sustainable development. In one module the actor analysis was conducted and the results (and open questions) werethe basis for a concluding seven day "summer school" in the region in which a lot of stakeholder contacts and collaboration took place. As a result of the study program recommendations and a SWOT analysis for further regional development paths were elaborated and presented to the public and regional decision makers.

\section{Step 1: Identifying actors}

The aim of the first step is to collect actors who are identified in an iterative process of searching and description. This working step is dependent on the research question. The

\footnotetext{
${ }^{4}$ Wiek et al.(2012) presented a well-structured approach for problem-oriented mapping. It gives a first understanding of drivers, causes, effects and relevant actors. This is a general preparatory step for research to enable the definition of purpose and goal of the research at hand.

${ }^{5}$ MOSUR: http://mosur.czp.cuni.cz/en/

${ }^{6}$ DBU: Deutsche Bundesstiftung Umwelt, https://www.dbu.de/

${ }^{7}$ Additional information can be found in the projects website under

http://www.czp.cuni.cz/ispos/index.php/for-students/what-is-ispos
} 
result of this collection process is a list of actors, and depending on the guiding question, a range from only a few to many ( $>40$ ) actors could be possible. Returning to the definition of actors, individuals or a collective of actors could be relevant.

Information sources to search and select actors embrace the full set of social research methods from literature review to interviews with external or local experts and people; from brainstorming to snowball-sampling (cf. Newig 2012, Reed et al. 2009), as it is often helpful to talk to informants (resource persons) who are familiar with the issue and can describe the other relevant actors. These conversations could focus on the following questions:

- "Who would you go to in order to learn more about the given issue?

- Who defines the rules in relation to the given issue?

- Who has particular knowledge and important resources in relation to the given issue?

- Who has a variety of relationships to other actors concerned with the given issue?" $(\mathrm{GTZ}, 2007,12)$

Different heuristics can help to structure the collection process:

STEEP-formula: Social, Technological, Environmental, Economic and Political spheres (e.g. described in Lynch 2012) might be relevant for the case, and actor identification can be structured along these spheres. These spheres can also be split up for more detailed analyses (e.g. administration, science, civil society, etc.).

Another option for guiding the sampling of actors could be along the lines of the different roles concerning the guiding question. Very often, roles in the context of an environmental problem are "polluters" (they cause the problem or have an interest in continuing to pollute); "helpers" (they have an interest in solving the problem); and "victims" (who are affected by the problem or have an interest in reducing pollution) (cf. also "analytical triangle of political science" von Prittwitz, 2007).

\section{Box 2: Example Actors - (Lignite) Mining in the Ore Mountains}

Local people, the German population on the border, diverse NGOs, the Czech Coal company, local government, local governors, media, state government, the wood industry, local tourism, cultural organizations, etc.

\section{Step 2: Selection of key actors, characteristics of actors}

After having collected a range of actors, it often makes sense to reduce the broader inventory to 8 to 12 key actors that set out the following steps of analysis. Criteria for key actor selection depend on the research question. According to Reed et al. (2009), approaches to assess (key) actors follow either a top-down "analytical categorisation" approach or a bottom-up "reconstructive method". Both approaches use a multi criteria assessment. While in the reconstructive method the actors themselves define the criteria or parameter for categorization, in the top down approach the criteria are defined by the research or case study team.

These chosen criteria should be relevant for the research questions; examples for criteria are given in box 3 . 


\section{Box 3: Example criteria for stakeholder categorization}

- $\quad$ Roles and legitimacy (institutional status, acquired rights, etc.)

- Resources (financial, personal, time, knowledge, etc.) and responsibility

- Relationships/degree of interrelatedness (amount and stability of relationships to other actors)

- Power

- Urgency (cf. Crosby, 1992; Brugha \& Varvasovszky, 2000; GEZ, 2007)

- Responsibility (present or possibly legal, contractual, or other political responsibilities)

- Influence (on actions or decisions)

- Closeness (interactions, long lasting relationships, dependence)

- Dependence (direct or indirect)

- Representation (of different interest positions)

- $\quad$ Strategic goals (AA1000SES, 2011)

Table 1: Example of multi criteria assessment key actors

\begin{tabular}{|l|c|c|c|}
\hline \multirow{2}{*}{$\begin{array}{l}\text { Potential key ac- } \\
\text { tor }\end{array}$} & $\begin{array}{c}\text { Roles and Legiti- } \\
\text { macy }\end{array}$ & $\begin{array}{c}\text { Resources \& re- } \\
\text { sponsibility }\end{array}$ & Relationship \\
\hline Mining Company & 2 & 3 & 3 \\
\hline Local Inhabitants & 3 & 1 & 2 \\
\hline Cultural NGO & 3 & 1 & 1 \\
\hline$\ldots$ & & & \\
\hline
\end{tabular}

Legend: $1=$ weak, $2=$ medium, $3=$ strong

Often this assessment is realized in a simple table, as is shown in Table 1. (above). This table can be translated into a figure, and the actors rated in "medium" or "strong" category ("2" or "3") can be placed in the corresponding circle, as shown in Figure 1. Actors who reach " 2 " or " 3 " in at least two circles are considered to be key actors as they inherit at least two of the important core functions/criteria (A1 through A4 in this case) ${ }^{8}$.

\footnotetext{
${ }^{8}$ Another example can be found in Mitchell et al. (1997: 874).
} 


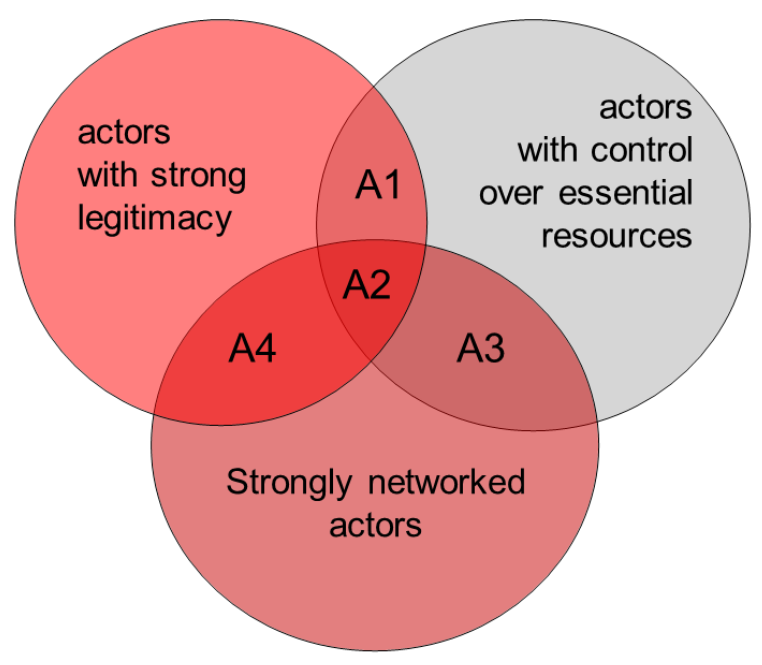

Figure 1: Scheme for selecting key actors

\section{Step 3: Analyzing and describing (relationships) between actors}

In depth characterization of the actors is the central part of an actor analysis. The aim of this step is to gain deep insight in relevant actors' characteristics and actor relations.

Literature offers many methods to characterize or define their deficiencies and potentials as well as to identify similar or differing actors. Often, the option to assess actors against two or more indicators/categories is used. Basically, it can be helpful to build indicators or categories which are informed, for example, by political or social science theories, in order to set up an analytical scheme for the characterization of actors (cf. step 2). What are helpful are e.g. theories about different forms of power (and uses of power), the understanding of roles (polluters, helpers, etc.), or aspects of influence and importance. Then the values for the variables within categories should be determined, for example, using a scale from -2 to 2 , or ordinal values like active, passive, or indifferent. Here the methods of empirical social research offer many possibilities. Very often the categories 'influence' and 'involvement' are used. ${ }^{9}$

If more than one or two categories shall be analyzed, actor profiles can be developed. This method is recommended, for example, for case studies on regional development or change management and can be used to generate profiles of actors in order to identify their differences and similarities, and to test and discuss/evaluate strategic options (GTZ, 2007). Multi criteria actors' characteristics, for example their interests, resources or influence, are represented by an inventory of actor profiles.

In the Ore Mountains case study actor profiles have been developed. Characteristics that were included in the actors' profiles depend on the research question. These categories/criteria for actor profiles should be discussed in a team and carefully defined (content, amount of criteria) in correspondence with the case study focus. An example on how to summarize characteristics of key actors in a detailed profile is illustrated in Table Chyba!

${ }^{9}$ A very detailed description of this method is given in GTZ, 2007. 
Nenalezen zdroj odkazů.2. The knowledge for setting up the graphs results from a comparison of the different actor profiles. During the case study, interviews with these actors and desktop research delivered data for setting up the profiles. The actor profiles offer a useful basis for visualizing actors' relative importance and for deciding which relationships among which actors should be built up and consolidated.

Table 2: Actor profiles (criteria are taken from case study (Lignite) Mining in the Ore Mountains; Graphs are anonymized)

\begin{tabular}{|c|c|c|c|c|}
\hline Indicator / Categories & -- & + & ++ & Description \\
\hline $\begin{array}{l}\text { \# } 1 \text { Development vision: The actor is aware of the problems in the } \\
\text { region. He supports a constructive vision of sustainable development } \\
\text { based on democracy \& the balancing of interests. He is willing to } \\
\text { change the situation, searches for a long-term solution, and con- } \\
\text { siders all of the relevant information regardless of its origins. He has a } \\
\text { broad vision. }\end{array}$ & & & & \\
\hline $\begin{array}{l}\text { \# } 2 \text { Flexibility and innovation: The actor is open to new ideas and } \\
\text { adapts his/her/its organization to new challenges. He is tolerant, open } \\
\text { to criticism, impartiality and the possibility of understanding other key } \\
\text { players. He is willing to learn and to change. }\end{array}$ & & & & \\
\hline $\begin{array}{l}\text { \# } 3 \text { Relationships: The actor facilitates contacts, creates spaces in } \\
\text { which encounters can occur and adapts his/her/its actions to the ca- } \\
\text { pacity of his/her/its external partners. }\end{array}$ & & & & \\
\hline $\begin{array}{l}\text { \# } 4 \text { Communication: The actor has a consistent view of his/her/its } \\
\text { goals (communication within the actor). He keeps others informed of } \\
\text { his/her/its interests, goals and activities. He participates in the ex- } \\
\text { change of information and answers queries promptly. }\end{array}$ & & & & \\
\hline $\begin{array}{l}\text { \# } 5 \text { Transparency: The actor acts on the basis of transparent guide- } \\
\text { lines and strategies, and clarifies roles and responsibilities in his/her/its } \\
\text { organization. }\end{array}$ & & & & \\
\hline $\begin{array}{l}\text { \# } 6 \text { Trust: The actor informs others proactively and transparently } \\
\text { about his/her/its intentions, aims, objectives and expectations, and } \\
\text { shows understanding for other interests. The actor keeps to agree- } \\
\text { ments and fulfils the relevant requirements on schedule. }\end{array}$ & & & & \\
\hline $\begin{array}{l}\text { \# } 7 \text { Operational effectiveness: The actor works in a goal-oriented } \\
\text { and results-driven way and periodically checks the extent to which } \\
\text { goals have been achieved. }\end{array}$ & & & & \\
\hline $\begin{array}{l}\text { \# } 8 \text { Conflicts: The actor is quick to flag tensions and conflicts and is } \\
\text { prepared to tackle them constructively, openly and quickly. }\end{array}$ & & 3 & & \\
\hline $\begin{array}{l}\text { \# } 9 \text { Resources: The actor is financially independent and therefore not } \\
\text { bound to and dependent on the other actors. }\end{array}$ & & & & \\
\hline
\end{tabular}

Description: if you work in groups and the first actor profiles are shared to be prepared by a single person, the right column could be used to add more (detailed) information then in the previous table. 


\section{Discussion}

Sometimes one can see in a case study practice that an analysis stops with the description of the gathered data and results. The last step in the sound application of the method is the integration and interpretation of the results: one must answer the research/case study question.

This step can include the structuring of the data and graphical representations (also for communication of the results). If applicable, a comparison with the underlying hypotheses and an interpretation of the results in this context should be done. Often, especially in a case study context, one goal is to develop strategies (e.g. for interventions or involvement of actors, steering of participatory processes, etc.). Some results of these discussions are presented in a shortened and "anonymized" form in Box 4.

\section{Box 4: Example evaluation of results:}

\section{Guiding questions for actor analysis (Lignite Mining in Ore Mountains)}

Which actors are relevant in this context? Which interactions take place? Who is affected or has an interest? What is the relevance of each role player for the process of change?

\section{Evaluation/Results:}

- Relevant actors are the mining company, local governors, population, actor d, actor e, ...

- "Polluter/Destroyer" is the mining company with strong support from the state and actors $\mathrm{d} / \mathrm{e}, \ldots$

- The population and governor are victims of the situation, especially in that they have a lack of influence, and some connections in their communication network are very weak. Generally, victims are not able to organize their goals in unison and do not follow a common strategy for resistance. ...

- A proposal for a strategy to achieve sustainable regional development could be:

- Building an alliance for all victims, offering support for organizing goals and communication structures.

- $\quad$ The mining company should be spoken to directly in order to integrate them into the reform intervention. The way that their involvement is structured must ensure that the reasons and arguments put forward for their negative attitude can be made explicit and taken into account.

- Actors $e$ and $f$ have been identified as important holders of resources and should be involved in the negotiation process.

-

Basically, what is important is a critical reflexion of actor analysis' results and whether the process was adequate to reach the predefined goals. This step can be accomplished using the case study team together with the involved actors. It is important to remember here that (in many cases) the actor analysis is only a part of the entire case study which implies different evaluation levels. Following questions are relevant for thë actor anbalysis at the end of the whole case study research:

- Did the actor analysis include all relevant characteristics for the conclusions (e.g. emotions of actors)?

- How should one assess the expressiveness of the chosen indicators (e.g. for power, or operational effect)? 
In this article we highlighted the identification of actors and key actors as well as their characteristics and individual profiles. A forecast of decisions or actions is not possible as human decisions are often irrational and influenced by emotions and other constraints (resources availability, interests etc.). Thus actor analysis can illustrate the current state of actors and their profiles that can change over time. Additional application of actor analysis is possible in combination with social network analysis (e.g. Schnegg 2010) to gain deeper and more sophisticated insights into network constellations e.g. strong and weak relations. Network analysis can be used to identify communication and information patterns and other relationships between actors in networks.

\section{Conclusion}

The three steps presented in this article are an orientation of how an actor analysis could be carried out in a context of case studies on regional sustainable development, and are underlined by different examples and methods of how to analyze qualitative or quantitative data.

A structured procedure in actor analysis facilitates the implementation of the method and is important for comprehensible and transparent results. In practice it is necessary to strike a balance between practical and real system limits - in some cases it is difficult to recognize the limits and it is also recommended to stay with a reasonable number of key actors. Additionally - even in a sound actor analysis the selection and definition of actors by criteria, these criteria are rated by (a group of) humans and therefore might be subjective decisions. Finally, it is important to mention that an actor analysis can only help to gain insight into social (-environmental) systems and interactions - it does not deliver a "model".

These previously discussed limits to actor analysis are at the same time the strengths of actor analysis, especially in processes of sustainable regional development as it becomes obvious how important actors, their resources, intentions and other characteristics are. Transition processes are controlled by social players and these are the ones who finally decide and interact. Actor constellations can be investigated by actor analysis with a practical relevance in order to contribute (information) for sustainable solutions.

This study provides an overview of actor analysis within research projects on regional sustainable development, including examples from the case study on mining in the Ore Mountains region. In the Ore Mountains case study example, possible alliances, strategic interest, and willingness to cooperate are criteria included in the actor profiles which were evaluated and brought together in a proposal ("vision") for a development plan for the Ore Mountain region, including a SWOT analysis. These results were presented in a public place. The results showed that sustainable regional development is dependent on different actors interests and resourcs and that different knowledge types of knowledge and different system understandings are present in that region. In order to tackle a sustainable solution path that "fits" local demands, individual actors and their decisions are important, as is a dialogue between the relevant actors. The Ore Mountain case study identified relevant actors and strategic options for regional sustainable development by applying a systematic actor analysis approach.

Actor analysis shows potentials can be a valuable tool for (transdisciplinary) research projects and case studies, e.g. in sustainability science, which can be applied flexibly and adapted for specific cases. The specificities of this potential, e.g. a well-structured approach for more quality and integration of results, needs to be investigated further. 


\section{Acknowledgement}

The article was supported by the Technology Agency of the Czech Republic, project TD020120 (Analysis and support for participatory decision-making processes aimed at regional susta-inable development strategies through the use of actor analysis method).

\section{References}

- AA1000 Stakeholder Engagement Standard 2011. Final Exposure Draft. AccountAbility (2011). : AA1000SES Technical Committee 2011. Retrieved from http://www.accountability.org/images/content/5/4/542/AA1000SES\%202010\%20 PRINT.pdf

- $\quad$ Ackermann, F., \& Eden, C. (1998). Making Strategy: The Journey of Strategic Management. Sage Publications, London. London: Sage Publications.

- Ackermann, F., \& Eden, C. (2003). Powerful and Interested Stakeholders Matter: Their Identification and Management. Management Science Working Paper No. 2.. .

- Borgatti, S. P., Everett, M. G., \& .Freeman, L.C., (2002). Ucinet for Windows: Software for Social Network Analysis. Harvard, MA: Analytic Technologies.

- Brugha, R., \& Varvasovszky, Z. (2000). Stakeholder Analysis: a Review. Health Policy Planning, 15(3), 239-246. pmid:11012397

- Clark, W. (2001). Research Systems for a Transition Toward Sustainability. GAIA. Bd., 10(4), 264-266.

- Crosby, B. (1991). Stakeholder Analysis: A Vital Tool for Strategic Managers. USAID's Implementing Policy Change Project. Technical Notes, No.2. USAID?s Implementing Policy Change Project. Technical Notes, No.2. Available online under: http://pdf.usaid.gov/pdf docs/pnabr482.pdf (30.12.2013. Retrieved from http://pdf.usaid.gov/pdf docs/pnabr482.pdf

- $\quad$ Crutzen, P. (2006) The "Anthropocene". In E. Ehlers \& T. Krafft (Eds.), Earth System Science in the Anthropocene (pp. 13-18). Berlin, Heidelberg: Springer-Verlag.

- Dlouhá, J., a Burandt, S. (2015). Design and evaluation of learning processes in an international sustainability oriented study programme. In search of a new educational quality and assessment method. Journal of Cleaner Production, 106, pp. 247-258 http://dx.doi.org/10.1016/j.jclepro.2014.09.096

- European_Commission, (2003). Common Implementation Strategy for the Water Framework Directive (2000/60/EC). Guidance document No.8. Public Participation in relation to the Water Framework Directive. Luxembourg: Office for Official Publications of the European Communities.

- $\quad$ Evans, Christen, Velarde, Sandra J., Prieto, Rocio P., Rao, Sheila N., Sertzen, Sandra, Dávila, Karina, Cronkleton, Peter and de Jong, Will, (2006) Field guide to the future: four ways for communities to think ahead. In Bennett, Elena and Zurek, Monika (Ed.), Center for International Forestry Research (CIFOR), Indonesia, ASB Partnership for the Tropical Forest Margins. Nairobi, Kenya: World Agroforestry Centre. 
- Frischknecht, Peter and Schmidt, Barbara, (2002). Umgang Mit Umweltsystemen: Methodik zum Bearbeiten von Umweltproblemen unter Berücksichtigung des Nachhaltigkeitsgedankens. München: ökom Verlag.

- Gralla, F., \& John, B. (2013). Akteursanalyse. Werkstatt 1. Lüneburg: Leuphana University.

- Gray, B. (1989). Collaborating: Finding Common Ground for Multiparty Problems. San Francisco: Jossey-Bass.

- Graymore, M. L., Sipe, N. G., \& Rickson, R. E. (2008). Regional sustainability: How useful are current tools of sustainability assessment at the regional scale?. Ecological Economics, 67(3), 362-372. http://dx.doi.org/10.1016/j.ecolecon.2008.06.002

- GTZ_Deutsche_Gesellschaft_für_Technische_Zusammenarbeit, (2007). Mainstreaming Participation. Multi-stakeholder management: Tools for Stakeholder Analysis: 10 building blocks for designing participatory systems of cooperation. From the series: Promoting participatory development in German development cooperation. Eschborn: Federal Ministry for Economic Cooperation and Development. Retrieved from http://www.fsnnetwork.org/sites/default/files/en-svmp-instrumenteakteuersanalyse.pdf

- Hermans, L. (2005). Actor Analysis for Water Resources Management. Putting the Promise into Practice. Delft: Eburon Uitgeverij.

- Lynch, R. L. (2012). Strategic management. 6. ed. Harlow, Essex: Pearson (Always learning.

- Mader, C. (2009). Principles for integrative development processes towards sustainability in regions. : University of Graz.

- Mitchell, Ronald K., Agle, Brandley R. and Wood, Donna J., (1997). Toward a Theory of Stakeholder Identification and Salience: Defining the Principle of Who and What Really Counts. Academy of Management Review, 22(4), 853-886. http://dx.doi.org/10.5465/AMR.1997.9711022105

- Newig, J. (2012). Actor and Stakeholder Analysis. Lecture: Methods in Inter- and Transdisciplinary Research. Lüneburg: Leuphana University.

- Reed, M. S., Graves, A., Dandy, N., Posthumus, H., Hubacek, K., Morris, J., . . Stringer, L. C. (2009). Who's in and why? A typology of stakeholder analysis methods for natural resource management. Journal of Environmental Management, 90(5), 1933-1949. http://dx.doi.org/10.1016/j.jenvman.2009.01.001

- Rockstrom, J., Steffen, W., Noone, K., Persson, A., Chapin, F. S., Lambin, E. F., ... Foley, J. A., (2009). A safe operating space for humanity. Nature, 461(7263), 472475. http://dx.doi.org/10.1038/461472a

- Schimank, U. (2007). Handeln und Strukturen. Einführung in die akteurstheoretische Soziologie. 3. Auflage. Weinheim-München: Juventa Verlag.

- Schnegg, M. (2010) Ethnologie. In Stegbauer \& Häußling (Eds.), Handbuch der Netzwerkforschung. Wiesbaden: VS Verlag. 
- The_BACC_Author_Team (2008). Assessment of Climate Change for the Baltic Sea Basin. : Springer Verlag.

- von_Prittwitz, V. (2007). Vergleichende Politikanalyse [Comparative Political Analysis]. Stuttgart: Lucius\&Lucius UTB.

- Wever, L., Krause, G., \& Buck, B. H. (2015). Lessons from stakeholder dialogues on marine aquaculture in offshore wind farms: Perceived potentials, constraints and research gaps. Marine Policy, 51, 251-259.

http://dx.doi.org/10.1016/j.marpol.2014.08.015

- Wiek, A., Ness, B., Schweizer-Ries, P., Brand, F. S., \& Farioli, F. (2012). From complex systems analysis to transformational change: a comparative appraisal of sustainability science projects. Sustainability science, 7(S1), 5-24. http://dx.doi.org/10.1007/s11625-011-0148-y

- Yin, R. K. (2014). Case study research: Design and methods (5. ed). Los Angeles, Calif.: Sage. 